\title{
Information Systems and their Effect on Organizational Performance: An Inquiry into Job Satisfaction and Commitment in Higher Education Institutions
}

\author{
Sergio Araya Guzmán ${ }^{1 *}$, Patricia Figueroa Fóster ${ }^{1}$, Patricio Ramírez-Correa ${ }^{2}$, Elizabeth E. Grandón ${ }^{1}$, \\ Jorge Alfaro-Perez ${ }^{2}$
}

${ }^{1}$ Faculty of Business Sciences, University of Bio-Bio, Concepción, CHILE

${ }^{2}$ Engineering School, Catholic University of the North, Coquimbo, CHILE

*Corresponding Author: saraya@ubiobio.cl

Citation: Guzmán, S. A., Fóster, P. F., Ramírez-Correa, P., Grandón, E. E. and Alfaro-Perez, J. (2018). Information Systems and their Effect on Organizational Performance: An Inquiry into Job Satisfaction and Commitment in Higher Education Institutions. Journal of Information Systems Engineering \& Management, 3(4), 26. https://doi.org/10.20897/jisem/3937

Published: November 10, 2018

\begin{abstract}
This work, which is a first advance of a project in development, presents a study whose objective is to establish if the success of information systems affects the job satisfaction and job commitment among the people, affecting the organizational performance considering as a study area the university education institutions. It is also analyzed if certain capacities associated with information systems can influence the success of these systems. To this end, surveys have been applied to non-academic professionals with at least one year of seniority in the institution and who use information systems as a support tool in their usual work. Given that this study is in the process of development, an analysis of the results obtained for 50 people surveyed from these institutions is presented. The analysis of results indicates that there are capacities associated with information systems that influence the success of these systems, and that this success affects job satisfaction and job commitment, and through the latter to organizational performance.
\end{abstract}

Keywords: information systems, university education institutions

\section{INTRODUCTION}

Information Systems (IS) are used in all types of organizations and by people at all organizational levels, who expect these systems to meet their requirements, translating this in turn into user satisfaction, which is a key factor for the success of IS, thus contributing to the achievement of expected results or performance of the organization (Calderón and Rodríguez, 2010). The success of IS can be measured through different variables. The Delone and Mclean model (Delone and Mclean, 2003), for example, measures this success by means of six variables, which are directly related to the effect that these systems can have on the development of the tasks and activities of their users, affecting their perception of aspects related to their work, and therefore, to the characteristics of the organization, influencing their attitude and behavior, which are directly related to the job satisfaction and commitment of people (Sánchez et al., 2013), which may have an effect on the achievement of organizational objectives and/or organizational performance (Rodríguez et al., 2011; Sánchez et al., 2013).

This study, which is a first advance in a project under development whose objective is to establish whether the success of IS affects the job satisfaction and commitment of people, impacting the performance of the organization, considering as a field of study Institutions of University Higher Education, presents the first results 
obtained after applying measurement instruments to non-academic professionals with at least one year of seniority in the institution and who use IS as a support tool in their regular work.

\section{REVISION OF LITERATURE AND RESEARCH MODEL}

IS are one of the most relevant components of the current business environment, offering opportunities of success for companies, because they have the ability to collect, process, distribute and share data in a timely and integrated manner (Abrego et al., 2017). In this sense, the incorporation of new information and technologies systems in a company is justified by the generation of information that contributes to improving the decisionmaking process and, therefore, competitiveness and organizational performance (Medina et al., 2012).

In addition, it is possible to propose that for IS to have any effect on the performance of organizations, it is not enough to say that they must have certain capabilities in the area of IS, such as competent IT personnel, but that they must also have the capabilities of people who are not in the IT area, such as users who use IS on a daily basis and/or managers from other areas who understand the benefits they can obtain, if they have adequate IS. In this context, Araya et al. (2006) argue that there are certain capabilities that are directly related to IS and these, in turn, have to be supported by certain capabilities that are indirectly related to IS, being these the ones indicated below: (i) Technical Capabilities associated with IS/IT, which refers to the technical skills of the organization to successfully develop and use IS/IT; (ii) Managerial Capabilities associated with IS/IT, which refers to the abilities of the management of the organization to conceive, develop and exploit IS/IT applications to support the development of the activities and functioning of the organization in a successful manner; (iii) Organizational Capabilities associated with IS/IT, which refers to the organization's ability to develop organizational aspects that can facilitate the successful conception, development and exploitation of IS/IT.

Users expect IS to meet their needs, which establishes their satisfaction with them, and this satisfaction of the end user is a key factor for the success of the IS, which will contribute obtaining the expected benefits (Calderón and Rodríguez, 2010; Sá et al., 2017). In this sense, models such as Delone and Mclean (Delone and Mclean, 2003), which is referenced by several authors (Ayala, 2012; Calderón and Rodríguez, 2010; Ramírez and García, 2005), measure the success of IS by means of six variables: Quality of information, Quality of the system, Quality of service, use/usability, Net benefits and User satisfaction. Regarding the latter variable Medina et al. (2009) point out that user satisfaction with IS is important because of their potential effects on the organization's goals, quality of life at work and willingness to use these systems.

Then, the perception that users may present of the IS could affect their perception of aspects related to their work and, therefore, to the characteristics of the organization, affecting their attitude and behavior, which are directly related to people's job satisfaction and commitment (Sánchez et al., 2013). In this sense, Chiang and San Martín (2015) argue that job satisfaction is "a globalizing concept with which reference is made to people's attitudes towards various aspects of their work", while job commitment can be understood as "a psychological state that characterizes the relationship between a person and an organization, which has consequences regarding the decision to continue in the organization or to leave it" (Meyer et al., 1993), or as "the force with which an individual feels linked to an organization and which implies following a relevant course of action for the organization" (Juaneda and González, 2007).

It can be seen that job commitment is a factor that affects the achievement of the objectives of institutions or companies, and that the fact that the workers of such organizations feel committed and satisfied with what they do (or with the organization itself) will allow them to perform in the best possible way facilitating the achievement of the objectives of the organization (Medina, 2005). Along the same line of thought, Rodríguez et al. (2011) argue that there is a clear and direct relationship between job satisfaction and performance, so that those who are satisfied with their work perform better and are more productive.

In relation to organizational performance, Barra and Gómez (2013) point out that the analysis about the achievement of greater performance or improvement is a recurring concern in all organizations, and therefore, the exploration of certain variables that lead to an increase in the value of the organization is considered relevant. In recent decades, models have been developed to measure organizational performance, focusing on the study of people's behavior to improve results (Barra and Gómez, 2013).

Organizational performance has been a topic of growing interest to organizations in general. In this regard, higher education institutions have also been concerned with improving their performance levels due, for example, to the overcrowding of higher education systems and limitations in public spending (Araya et al., 2007). In these organizations, in addition, technological changes and the use of IS present an important advance, which has been caused, to some extent, by facing an increasingly demanding and competitive educational environment (Araya and Chaparro, 2005). These demands have become a real challenge for these types of institutions, where there has been a growing interest in improving efficiency in the use and management of their human, financial, material, technological and information resources (Araya, et al., 2018). In this context, we propose the following hypotheses: 
Table 1. Reliability and Validity Indices

\begin{tabular}{lccc}
\hline Variable & Alfa de Cronbach & Compound reliability & Average variance extracted (AVE) \\
\hline GQ & 0.90 & 0.93 & 0.72 \\
\hline IQ & 0.89 & 0.92 & 0.69 \\
\hline SQ & 0.92 & 0.94 & 0.77 \\
\hline SF & 0.93 & 0.95 & 0.79 \\
\hline DM & 0.96 & 0.97 & 0.86 \\
\hline UU & 0.94 & 0.95 & 0.81 \\
\hline
\end{tabular}

Table 2. Discriminant Validity

\begin{tabular}{|c|c|c|c|c|c|c|}
\hline Variable & GQ & IQ & SQ & SF & DM & $\mathbf{U U}$ \\
\hline GQ & 0.85 & & & & & \\
\hline IQ & 0.83 & 0.83 & & & & \\
\hline SQ & 0.48 & 0.46 & 0.88 & & & \\
\hline$\overline{\mathrm{SF}}$ & 0.81 & 0.86 & 0.38 & 0.89 & & \\
\hline$\overline{\mathrm{DM}}$ & 0.69 & 0.70 & 0.56 & 0.73 & 0.93 & \\
\hline UU & 0.76 & 0.76 & 0.41 & 0.78 & 0.76 & 0.90 \\
\hline
\end{tabular}

H1: The Managerial Capabilities associated with IS have a positive impact on the success of IS.

H2: The Technical Capabilities associated with IS have a positive impact on the success of IS.

H3: The Organizational Capabilities associated with IS have a positive impact on the success of IS.

H4: The success of IS has a positive impact on the job satisfaction of people in a higher education institution.

H5: The success of IS has a positive impact on the job commitment of people in a higher education institution.

H6: Job satisfaction of people in a higher education institution has a positive impact on organizational performance.

H7: The job commitment of people in a higher education institution has a positive impact on organizational performance.

\section{METHODOLOGY}

The validation of the proposed hypotheses considers an empirical study carried out in institutions of University Higher Education in Chile, applying measurement instruments to non-academic professionals with at least one year of seniority in the institution and who use IS as a support tool in their usual work. Given that this study is under development, an analysis of the results obtained for 50 people surveyed in this first stage, from the same institution, is presented.

Data collection is carried out using instruments already defined and used in other studies, specifically: measurement of capabilities associated with IS/IT used by Araya et al. (2006); measurement of IS success defined by Medina (2005); measurement of job satisfaction used by Chiang and Gomez (2017); measurement of job commitment used by Meyer et al. (1993); organizational performance defined by Cardona and Calderón (2006). The instruments use a five-point Likert scale, where one is the lowest value and five the highest value. Statistical analysis of the data was carried out using a model of structural equations based on PLS and using the SmartPLS software.

\section{RESULTS}

The analysis in PLS was carried out in two phases; in the first phase, the six dimensions of the success of IS were evaluated to form, with their standardized scores, a second order formative variable that would be used in the second phase. In the second phase, the measurement and structural models associated with the research model were evaluated.

The six dimensions of success of the IS evaluated are system quality in general (GQ), information quality (IQ), service quality (SQ), decision making (DM), satisfaction (SF) and use-utility (UU). The evaluation of each dimension of IS's success indicated that the totality of the factorial loads was higher than the established $(0.7)$, Table 1 shows their reliability and validity indexes, and Table 2 the analysis of their discriminant validity using the Fornell-Larcker criterion.

The research model integrates seven variables: Managerial Capabilities (MC), Organizational Capabilities (OC), Technical Capabilities (TC), Success of the IS (ISS), Job Satisfaction (JS), Job Commitment (JC) and Organizational Performance (OP). The evaluation of each variable of the research model showed that the totality of the factorial loads was higher than required (0.7). Table 3 shows their reliability and validity indices. Table 4 shows the analysis 
Table 3. Reliability and Validity Indices of the Research Model

\begin{tabular}{lccc}
\hline Variable & Alfa de Cronbach & Compound reliability & Average variance extracted (AVE) \\
\hline MC & 0.91 & 0.93 & 0.66 \\
\hline OC & 0.81 & 0.88 & 0.64 \\
\hline TC & 0.88 & 0.91 & 0.58 \\
\hline C & 0.89 & 0.92 & 0.61 \\
\hline S & 0.86 & 0.89 & 0.63 \\
\hline OP & 0.87 & 0.90 & 0.65 \\
\hline
\end{tabular}

Table 4. Discriminant Validity of the Research Model

\begin{tabular}{lllllll}
\hline Variable & MC & OC & TC & JC & OP & JS \\
\hline MC & 0.81 & & & & & \\
\hline OC & 0.69 & 0.80 & & & \\
\hline TC & 0.58 & 0.62 & 0.76 & 0.78 & & \\
\hline JC & 0.18 & 0.34 & 0.30 & 0.70 & 0.81 & \\
\hline OP & 0.33 & 0.24 & 0.39 & 0.48 & 0.40 & 0.79 \\
\hline JS & 0.28 & 0.22 & 0.28 & & \\
\hline
\end{tabular}

Table 5. Structural Analysis Results

\begin{tabular}{|c|c|c|c|}
\hline Hypothesis & Relationship & Beta Value & Significance \\
\hline $\mathrm{H} 1$ & MC->ISS & 0.08 & ns \\
\hline $\mathrm{H} 2$ & TC->ISS & 0.44 & $* * *$ \\
\hline $\mathrm{H3}$ & OC->ISS & 0.44 & ** \\
\hline $\mathrm{H} 4$ & ISS->JS & 0.42 & $* * *$ \\
\hline $\mathrm{H} 5$ & ISS->JC & 0.50 & $* * *$ \\
\hline H6 & $\mathrm{JS}->\mathrm{OP}$ & 0.08 & ns \\
\hline $\mathrm{H} 7$ & $\mathrm{JC}->\mathrm{OP}$ & 0.67 & $* * *$ \\
\hline
\end{tabular}

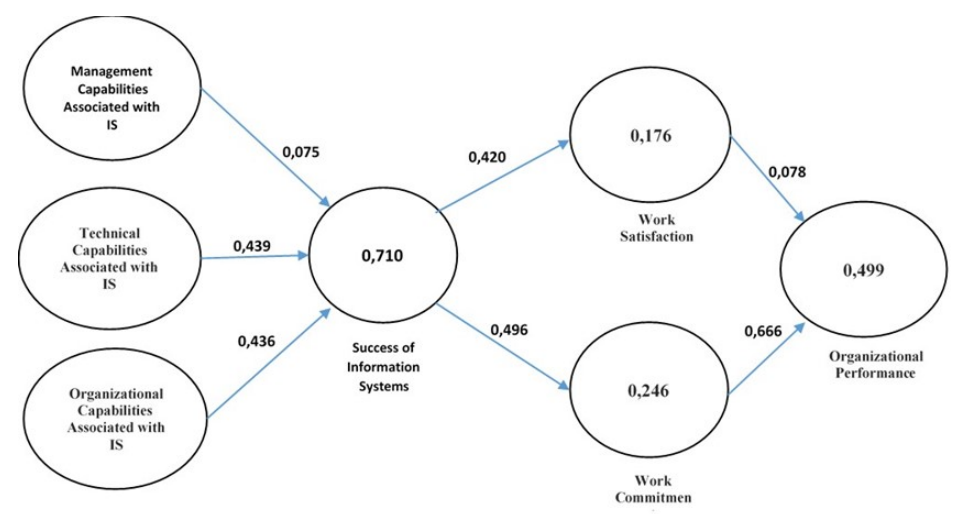

Figure 1. Structural Model

of their discriminant validity using the Fornell-Larcker criterion. These analyses support the goodness of the measurement model.

Table 5 shows the result of the analysis of the structural model, the bootstrapping method, with 1,000 subsamples, was used to calculate the significance of the beta values. Figure 1 details the structural model determination values.

Considering this analysis, hypotheses $\mathrm{H} 2, \mathrm{H} 3, \mathrm{H} 4, \mathrm{H} 5$ and $\mathrm{H} 7$ are supported, however it is not possible to support hypotheses H1 and H6.

\section{CONCLUSIONS}

Information Systems (IS) are increasingly used by all types of organizations, which must have a set of capabilities for these tools to be developed and used properly, constituting a mechanism that facilitates and collaborates in achieving the objectives established.

The results of this study show that of the three capabilities associated with IS considered in this study, it is technical capabilities the ones that have the greatest impact on the success of IS, followed by organizational capabilities, with the participation of managerial capabilities not being considered relevant. The above may indicate that, in the opinion of users, to ensure the use of IS aspects such as the characteristics of their design and 
construction (user-friendliness, ease of use, for example) or that they effectively support the development of their activities and tasks, or a culture favorable to IS, among others, are of greater relevance than, for example, the commitment of senior management to IS projects.

It has also been found that the success of IS does indeed have an impact on both job satisfaction and job commitment of users, but that when considering the effect of these variables on performance, only the job commitment has an impact. Given this last result, additional analyses were carried out, and it was found that since job satisfaction has an impact on job commitment, the effect of such relationship presents a greater impact on performance.

Notwithstanding the above, it is necessary to continue with the development of this study to have a greater number of valid surveys of people from different institutions, which may ratify the findings, reverse them or present new information, which should be discussed.

\section{REFERENCES}

Abrego, D., Sánchez, Y. and Medina, J. M. (2017). Influence of information systems on organizational results. Contaduría y Administración, 62(2), 321-338. https:/ / doi.org/10.1016/j.cya.2017.03.001

Araya, S., Figueroa, P., Grandón, E., Ramírez, P. and Alfaro, J. (2018). Exploring the relationship Information Systems and Organizational Performance, through Job Satisfaction and Labor Commitment in Universities. In Information Systems and Technologies (CISTI), 2018 13th Iberian Conference on (pp. 1-5). IEEE.

Araya, S. and Chaparro, J. (2005). Una aplicación del Análisis de Recursos y Capacidades en el ámbito de Instituciones de Educación Superior Universitaria (An application of the Analysis of Resources and Capabilities in the field of University Higher Education Institutions). Congreso de Ingeniería de Organización (CIO). Available at: http://www.adingor.es/Documentacion/CIO/cio2005/items/ponencias/110.pdf

Araya, S., Chaparro, J. and Orero, A. (2006). Propuesta de un modelo de relación entre capacidades asociadas con Sistemas y Tecnologías de Información y el desempeño de Instituciones Universitarias Palabras clave: Recursos y Capacidades de SI/TI, Desempeño de Universidades (Proposal of a relationship model between capabilities associated with Information Systems and Technologies and the performance of University Institutions Keywords: IS/IT Resources and Capabilities, University Performance). Congreso de Ingeniería de Organización (CIO). Available at: http://adingor.es/congresos/web/uploads/cio/cio2006/tic//000090_final.pdf

Araya, S., Chaparro, J., Orero, A. and Joglar, H. (2007). Sistemas y Tecnologías de Información y su relación con el Desempeño de Instituciones Universitarias en el ámbito de Gestión Institucional: un estudio desde la Teoría de Recursos y Capacidades (Information Systems and Technologies and their relationship with the Performance of University Institutions in the field of Institutional Management: a study from the Theory of Resources and Capabilities). In International Conference on Industrial Engineering \& Industrial Management (pp. 1805-1816). Congreso de Ingeniería de Organización (CIO). Available http:/ /www.adingor.es/congresos/web/uploads/cio/cio2007/information_systems_ict//1805_1816.pdf

Ayala, A. (2012). Evaluación del módulo de Recursos Humanos del Enterprise Resource Planning (ERP) en una empresa colombiana usando el modelo de Delone y Mclean (Evaluation of the Human Resources module of Enterprise Resource Planning (ERP) in a Colombian company using the Delone and Mclean modet). Universidad Nacional de Colombia. Available at: http://www.bdigital.unal.edu.co/8595/1/2822130.2012.pdf

Barra, A. and Gómez, N. (2013). Análisis del Rendimiento Organizacional a través del Modelo Gratton: Caso Aplicado a una Carrera de Pregrado de una Universidad Estatal Chilena (Analysis of Organizational Performance through the Gratton Model: A Case Applied to an Undergraduate Degree at a Chilean State University). Formación Universitaria, 6(4), 39-48. https://doi.org/10.4067/S0718-50062013000400005

Cardona, J. and Calderon, G. (2006). El impacto del aprendizaje en el rendimiento de las organizaciones (The impact of learning on organizational performance). Cuadernos de Administración Bogotá (Colombia), 19(32), 11-43.

Calderón, J. and Rodríguez, C. (2010). Un enfoque gerencial de factores críticos para el éxito de los sistemas de información en la Pyme metalmecánica venezolana (A management approach to critical factors for the success of information systems in Venezuelan metalworking SMEs). Contaduría y Administración, 57(1), 79-102.

Chiang, M. and Gómez, N. (2017). Satisfacción Laboral de trabajadores chilenos. Un Modelo de Ecuaciones Estructurales (Labor Satisfaction of Chilean workers. A Model of Structural Equations). Cuadernos de Administración, Revista de Administración y Negocios, 33(57), 48-60. https://doi.org/10.4067/S0718-24492015000300001

Chiang, M. and San Martín, N. (2015). Análisis de la satisfacción y el desempeño laboral en los funcionarios de la Municipalidad de Talcahuano (Analysis of job satisfaction and performance among officials of the Municipality of Talcabuano). Ciencia \& Trabajo, 17(54), 159-165.

Delone, W. and Mclean, E. (2003). The DeLone and McLean Model of Information System Success: A Ten-Year

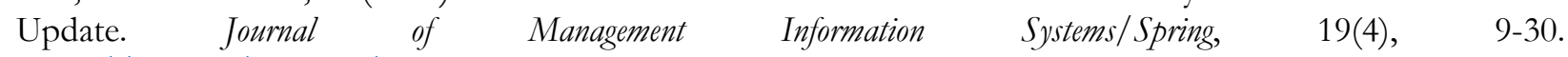
https://doi.org/10.1080/07421222.2003.11045748 
Juaneda, E. and González, L. (2007). Definición, Antecedentes y Consecuencias del Compromiso Organizativo (Definition, Background and Consequences of Organizational Commitment). Conferencia Conocimiento, innovación y emprendedores: camino al futuro, editado por Universidad de La Rioja, España.

Medina, J. (2005). Evaluación del impacto de los sistemas de información en el desempeño individual del usuario : aplicación en instituciones universitarias (Evaluation of the impact of information systems on individual user performance: application in university institutions). Available at: http://oa.upm.es/244/ https://doi.org/10.4301/S180717752009000100002

Medina, J., García, E. and De la Garza, M. (2009). Influence of the Implementation Factors in the Information Systems Quality for the User Satisfaction. Journal of Information Systems and Technology Management, 6(1), 25-44.

Medina, J., Lavín, J. and Pedraza, N. (2012). Seguridad en la administración y calidad de los datos de un sistema de información contable en el desempeño organizacional (Security in the administration and quality of the data of an accounting information system in organizational performance). Contaduría y Administración, 57(574), 11-34.

Meyer, J., Allen, N. and Smith, C. (1993). Commitment to organizations and occupations: Extension and test of a three-component conceptualization. Journal of Applied Psychology, 78(4), 538-551. https:// doi.org/10.1037/00219010.78.4.538

Ramirez, P. and Garcia, R. (2005). Success of ERP systems in Chile: an empirical study. In Proceedings of European, Mediterranean \& Middle Eastern Conference on Information Systems (pp. 1-16).

Rodríguez, A., Retamal, M., Lizana, J. and Cornejo, F. (2011). Clima y Satisfacción Laboral como predictores del desempeño: en una organización estatal Chilena (Climate and Job Satisfaction as predictors of performance: in a Chilean state organization). Salud \& Sociedad, 2(2), 219-234. https://doi.org/10.22199/S07187475.2011.0002.00007

Sá, F., Rocha, Á., Gonçalves, J. and Cota, M. P. (2017). Model for the quality of local government online services. Telematics and Informatics, 34(5), 413-421. https:// doi.org/10.1016/j.tele.2016.09.002

Sánchez, D., Reyes, R., Sekeres, M. and Ortiz, J. (2013). Satisfacción laboral y compromiso en las organizaciones de Rio Verde (Job satisfaction and commitment in Rio Verde's organizations), S.L.P. Revista de Psicologia y Ciencias del Comportamiento de la U.A.C.J.S., 4(1), 59-76. 